\title{
EFEK LAMA STIMULASI DAN TEGANGAN LISTRIK TERHADAP KOMPOSISI KIMIA, KUALITAS FISIK, DAN SENSORI DAGING AYAM PETELUR AFKIR
}

\section{EFFECT OF THE ELECTRICAL STIMULATION LENGTH AND VOLTAGES ON CHEMICAL COMPOSITION, PHYSICAL QUALITY AND SENSORY OF CULLED LAYER CHICKEN MEAT}

\author{
Adnan Syam ${ }^{1}$, Soeparno ${ }^{2 *}$, dan Rusman ${ }^{2}$ \\ ${ }^{1}$ Jurusan Peternakan, Fakultas Pertanian, Universitas Haluoleo, Jl. Mokodompit Bumi Tridharma, Kendari, 93232 \\ ${ }^{2}$ Fakultas Peternakan, Universitas Gadjah Mada, Jl. Fauna No. 3, Bulaksumur, Yogyakarta, 55281
}

\section{INTISARI}

Penelitian ini bertujuan untuk mengetahui efek lama stimulasi dan tegangan listrik terhadap komposisi kimia, kualitas fisik, dan sensori daging ayam petelur afkir. Penelitian ini menggunakan Rancangan Acak Lengkap pola faktorial 3 x 4 dengan 6 kali ulangan pada setiap kombinasi. Sampel penelitian adalah 72 ekor ayam petelur afkir yang dibagi menjadi 3 kelompok perlakuan dengan lama stimulasi 0, 1, dan 2 menit, dan 4 kelompok perlakuan stimulasi listrik 60, 75, dan 90 volt, dan kontrol dengan jumlah ulangan masing-masing 6 kali. Interaksi lama stimulasi dan tegangan listrik berpengaruh nyata terhadap kualitas fisik daging, yaitu $\mathrm{pH}$, daya ikat air, susut masak, keempukan, dan kadar protein daging. Stimulasi listrik selama dua menit dengan tegangan 90 volt dapat memperbaiki kualitas fisik daging ayam petelur afkir, dibandingkan dengan kombinasi lainnya. Interaksi antara lama stimulasi dan tegangan listrik dapat memperbaiki kualitas sensori daging yaitu keempukan, warna, aroma, dan tekstur daging ayam petelur afkir.

(Kata kunci: Ayam petelur afkir, Komposisi kimia, Kualitas fisik, Sensori, Stimulasi listrik)

\section{ABSTRACT}

The objective of the study was to evaluate the effect of the electrical stimulation length and voltages on chemical composition, physical quality and sensory of the meat of culled layer chicken. The study used a Completely Randomized Design of $3 \times 4$ factorial arrangement with six replications in each combination. Seventy-two samples of culled layer chicken were divided into 3 groups with length of stimulation of 0,1 and 2 minutes and 4 groups of electrical stimulation voltages of 60, 75 and 90 volt and control. There were significant interactions effect between stimulation length and voltages on meat physical quality, such as $\mathrm{pH}$, water-holding capacity, cooking loss, tenderness and meat protein. Electrical stimulation of 2 minutes with 90 volt improved physical quality, compared with other combinations. Stimulation length and electrical voltage significantly increased meat sensory quality, including meat tenderness, color, aroma and texture.

(Key words: Culled layer chicken, Chemical composition, Physical quality, Sensory, Electrical stimulation)

\section{Pendahuluan}

Daging dapat memberikan suatu kepuasan bagi manusia karena mempunyai nilai gizi tinggi, cita rasa yang enak dan lezat. Dewasa ini telah banyak dilakukan metode untuk memperbaiki dan atau mempertahankan kualitas daging, baik saat antemortem maupun postmortem. Metode yang digunakan antara lain: pada saat sebelum pemotongan penambahan enzim (antara lain: protease, papain, dan bromelin), perlakuan tekanan tinggi dan waktu yang pendek pada daging segar hewan yang dipotong maupun stimulasi listrik pada karkas. Daging yang berkualitas kurang baik diperoleh dari sumber daging yang kualitasnya rendah seperti daging ayam petelur afkir biasanya konsumen kurang menyukainya karena alot sehingga

\footnotetext{
* Korespondensi (corresponding author):

Telp. +62 81344441898

E-mail: soeparno_ugm@yahoo.com
}

mengurangi kenikmatan pada saat dikonsumsi, maka daging ayam petelur afkir tersebut perlu ditingkatkan kualitasnya salah satunya yaitu dengan metode stimulasi listrik. Konsumen dalam memiliki kualitas daging akan memperhatikan keempukan, rasa, juiciness daging sesudah dimasak (Palupi, 1986). Stimulasi listrik dapat pula meningkatkan kualitas daging dan dapat menurunkan kelarutan protein (Judge et al., 1989).

Salah satu sumber gizi yang dapat digunakan untuk memenuhi kebutuhan gizi masyarakat adalah dengan memanfaatkan daging ayam petelur afkir. Selama ini ayam petelur dimanfaatkan untuk produksi telur dan setelah diafkir dagingnya kurang diminati konsumen, padahal daging ayam afkir juga dapat menjadi bagian dari menu sehari-hari untuk memenuhi kebutuhan protein hewani. Banyak anggapan bahwa daging ayam afkir berkualitas rendah sebab dagingnya alot dan mempunyai aroma anyir sehingga tidak disukai oleh konsumen. Tingginya minat masyarakat Indonesia terhadap 
daging ayam membuat mereka tidak hanya mengkonsumsi daging ayam pedaging. Masyarakat juga mengkonsumsi daging ayam petelur yang sudah melewati masa produksi atau biasa disebut dengan ayam petelur afkir. Ayam jenis ini lapis kedua bagi persediaan daging ayam nasional (Anonimus, 2006).

Penerapan teknologi pasca panen berupa aplikasi stimulasi listrik dengan tegangan yang berbeda diharapkan dapat meningkatkan kualitas dan akseptabilitas daging ayam afkir. Hal ini disebabkan karena stimulasi listrik akan mempercepat proses glikolisis postmortem yang terjadi selama konversi otot menjadi daging dan dapat mengubah karakteristik palatabilitas daging (Soeparno, 2005). Stimulasi listrik terhadap karkas telah terbukti mempercepat habisnya ATP dan penurunan $\mathrm{pH}$ postmortem dan peningkatan keempukan daging.

Kualitas daging, termasuk keempukan dipengaruhi oleh faktor intrinsik ternak khususnya bangsa, spesies, jenis kelamin, dan umur pemotongan. Kombinasi yang tepat antara lama stimulasi listrik dengan tegangan berbeda diharapkan menjadi solusi peningkatan kualitas fisik, komposisi kimia dan sensori daging ayam petelur afkir. Denaturasi protein meningkat karena stimulasi listrik mampu mempercepat penurunan $\mathrm{pH}$ daging. Penurunan $\mathrm{pH}$ yang cepat akan meningkatkan aktivitas enzim proteolitik yang mampu mendenaturasi protein (Lawrie dan Ledward, 2006). Stimulasi listrik terbukti dapat meningkatkan keempukan, warna daging lebih cerah dan penurunan $\mathrm{pH}$ daging lebih cepat dibandingkan daging yang tidak distimulasi listrik (Solomon, 1986).

Penelitian ini bertujuan untuk mengetahui efek lama stimulasi listrik terhadap komposisi kimia, kualitas fisik, dan sensori daging ayam petelur afkir. Hasil penelitian ini diharapkan menjadi sumber informasi tentang dampak stimulasi listrik terhadap kualitas daging ayam petelur afkir sehingga dapat diketahui potensi daging ayam petelur yang telah diafkir.

\section{Materi dan Metode}

\section{Materi}

Materi yang digunakan adalah 72 ekor ayam petelur afkir strain Lohmann, berat hidup rata-rata 1,7 kg dengan umur kisaran 22 sampai 24 bulan. Alat yang digunakan adalah pisau, garpu, nampan, alat listrik, stopwatch, water bath (Memmert), timbangan, alat penguji keempukan ( $W$ - $B$ Shear Press), plastik polietilen, alat pengukur $\mathrm{pH}$ (Hanna Instrument), kertas tissue, gelas piala $100 \mathrm{ml}$, baskom, panci, kulkas, beban $35 \mathrm{~kg}$, pipet, alat pengaduk, akuades, termometer, oven, plat kaca, kompor, dan alat tulis menulis. Instrumen pengempuk yaitu alat stimulasi listrik (Dual Tracking Supply) berupa adaptor dengan kapasitas 0, 60, 75, dan 90 volt. Sampel sebanyak $50 \mathrm{~g}$ kemudian diambil untuk pengujian kadar protein dan lemak, karakteristik fisik dan sensori daging ayam petelur. Daging didapat dari ayam petelur yang mempunyai strain, umur, pakan, kisaran berat hidup, dan temperatur air saat scalding yang sama. Bahan kimia untuk uji kadar air adalah asam sulfat, asam boraks, dan $\mathrm{NaOH}$, untuk uji kadar lemak adalah kloroform dan metanol.

\section{Metode}

Pada sampel penelitian diambil daging bagian dada dari ayam petelur afkir yang dibagi menjadi 3 kelompok perlakuan dengan lama stimulasi yaitu 0 , 1, dan 2 menit dan 4 kelompok perlakuan tegangan listrik: kontrol, 60,75 , dan 90 volt dengan jumlah ulangan masing-masing 6 kali.

Sampel dalam penelitian ini yaitu ayam petelur afkir dipotong dengan metode halal (halal slaughter) yaitu memotong arteria carotis, vena jugularis, esofagus, dan darah dibiarkan keluar secara sempurna. Kemudian karkas dibersihkan dan dipisahkan dengan organ dalamnya. Selanjutnya persiapan sampel dengan menyiapkan water-bath yang dibutuhkan untuk persiapan percobaan daging. Sebelumnya akan dilakukan penelitian pendahuluan untuk uji coba instrumen sehingga mencegah terjadinya kesalahan dalam penelitian utama.

Karkas yang diperoleh dari ayam yang telah disembelih kemudian diacak dan diberikan kode berdasarkan perlakuan dan ulangan. Bagian karkas yang digunakan adalah bagian dada kiri maupun kanan tidak dibedakan. Perlakuan stimulasi listrik dengan voltase berbeda, yaitu tegangan 0 (kontrol), 60,75 , dan 90 volt masing-masing selama 1 dan 2 menit dengan frekuensi 50-60 Hz.

Cara perlakuannya yaitu menghubungkan kedua kutub listrik pada ujung dada (otot pectoralis). Semua perlakuan diterapkan secara sistematis dan diulang sebanyak masing-masing dua kali. Selanjutnya sampel dimasukkan ke dalam plastik polietilen untuk mendapatkan pengujian kualitas fisik, sensori, dan kimia diberi label. Label yang diberikan disesuaikan dengan kode perlakuan yang diterapkan kemudian dilipat memanjang dan dipres sehingga tidak terjadi kontak langsung dengan air (Soeparno, 2005).

\section{Peubah yang diamati}

Peubah yang diamati adalah kualitas fisik berupa $\mathrm{pH}$ daging, daya ikat air, susut masak daging, dan keempukan. Peubah komposisi kimia berupa kadar air, kadar protein daging, dan kadar lemak. Peubah sensori terdiri dari warna, rasa, tekstur, aroma, keempukan, dan daya terima. 


\section{Analisis data}

Data hasil uji kualitas fisik dan komposisi kimia dianalisis dengan analisis variansi dengan desain CRD pola faktorial $3 \times 4$ (Astuti, 1980). Faktor pertama adalah lama stimulasi dan faktor kedua adalah tegangan listrik. Apabila ada perbedaan dilanjutkan menggunakan uji Duncan's new Multiple Range Test (DMRT). Data hasil uji karakteristik sensori dianalisis dengan analisis statistik non parametrik menggunakan uji hedonik menurut Kruskal-Wallis (Santoso, 2003).

\section{Hasil dan Pembahasan}

\section{Kualitas fisik daging}

Kualitas fisik daging ayam petelur afkir yang digambarkan oleh derajat keasaman $(\mathrm{pH})$, daya ikat air (water-holding capacity), susut masak (cooking loss), dan keempukan (tenderness) ayam petelur afkir hasil penelitian disajikan pada Tabel 1 .

Perbedaan lama stimulasi listrik dengan tegangan yang berbeda menunjukkan pengaruh yang nyata terhadap $\mathrm{pH}$ daging ayam petelur afkir. Hal ini diduga cadangan glikogen yang terdapat dalam tubuh ayam relatif sedikit, sehingga perubahan pH-nya signifikan. Soeparno (2005) menyatakan bahwa perubahan konsentrasi nutrien daging yang terbesar adalah dari hasil degradasi cadangan glikogen melalui glikolisis yang dikonversikan menjadi asam laktat. Penimbunan asam laktat dan tercapainya $\mathrm{pH}$ ultimat otot pasca mati tergantung pada jumlah cadangan glikogen otot pada saat pemotongan.

Aberle et al. (2001) menyatakan bahwa glikolisis anaerobik tergantung pada jumlah glikogen otot pada saat pemotongan. Sementara itu Girard (1992) menyatakan bahwa otot ternak yang stres sebelum pemotongan mengandung cadangan glikogen yang sedikit dan penurunan $\mathrm{pH}$ daging dari ternak ini selama postmortem kurang dari hewan normal, hal ini karena kurangnya asam laktat yang terbentuk.

Penimbunan asam laktat terhenti setelah tercapai $\mathrm{pH}$ ultimat 5,4 sampai 5,8 (Lawrie dan Ledward, 2006). Pada penelitian ini $\mathrm{pH}$ yang dihasilkan masih lebih besar jika dibandingkan dengan $\mathrm{pH}$ ultimat, yang diduga bahwa ayam mengalami stres selama pengangkutan ke tempat pemotongan, sehingga cadangan glikogen dalam otot sangat sedikit dan $\mathrm{pH}$ juga menjadi tinggi. Hasil penelitian ini menunjukkan bahwa semakin tinggi tegangan yang digunakan maka mengakibatkan tingginya $\mathrm{pH}$ daging ayam petelur afkir $(\mathrm{P}<0.05)$. Rata-rata nilai $\mathrm{pH}$ dengan tegangan 0,60 , 75 , dan 90 volt masing-masing adalah $6,23,6,14$, 6,19 , dan 6,01 . Waktu stimulasi yang berbeda juga menunjukkan pengaruh yang nyata pada nilai $\mathrm{pH}$.
Rata-rata nilai $\mathrm{pH}$ untuk lama stimulasi 0,1 , dan 2 menit secara berurutan adalah 6,23,6,13, dan 6,06.

Perbedaan lama stimulasi listrik dengan tegangan yang berbeda berpengaruh nyata $(\mathrm{P}<0,05)$ terhadap daya ikat air daging ayam petelur afkir. Rerata daya ikat air menunjukkan adanya penurunan setelah dilakukan stimulasi listrik, yang berhubungan dengan adanya penurunan $\mathrm{pH}$. Tegangan yang lebih tinggi menghasilkan daya ikat air yang lebih rendah pada daging ayam petelur afkir. Rata-rata daya ikat air pada perlakuan stimulasi listrik $0,60,75$, dan 90 volt masingmasing adalah 41,$02 ; 30,29 ; 34,41$; dan $31,64 \%$.

Lawrie dan Ledward (2006) menyatakan bahwa penurunan daya ikat air disebabkan oleh penurunan $\mathrm{pH}$ dan konsekuensi dari protein pada titik isoelektriknya atau karena denaturasi protein. Hal ini juga diduga dikarenakan rusaknya filamenfilamen dan struktur serabut otot akibat stimulasi listrik sehingga menyebabkan penurunan daya ikat air. Selain itu protein otot mempunyai hubungan erat dengan air daging karena protein otot mempunyai sifat hidrofilik yaitu mengikat molekul air daging. Oleh karena itu, dengan rusaknya filamen protein dan struktur serabut otot maka daya ikat air oleh protein semakin menurun. Lawrie dan Ledward (2006) menyatakan bahwa stimulasi listrik dapat meningkatkan proteolisis dan kerusakan membran lisosomal.

Hasil penelitian menunjukkan bahwa waktu stimulasi listrik dan perbedaan tegangan berpengaruh nyata $(\mathrm{P}<0,05)$ terhadap daya ikat air daging ayam petelur afkir. Daya ikat air semakin menurun pada variasi waktu stimulasi. Hal ini terkait erat dengan kerusakan filamen protein dan struktur serabut otot yang dialami daging ayam petelur afkir.

Interaksi antara lama stimulasi listrik dengan tegangan yang berbeda berpengaruh nyata $(\mathrm{P}<0,05)$. Hasil rata-rata daya ikat air yang menunjukkan bahwa semakin tinggi stimulasi listrik dan semakin lama waktu stimulasi menghasilkan daya ikat air yang lebih rendah pada daging ayam petelur afkir.

Lama stimulasi listrik berpengaruh nyata $(\mathrm{P}<0,05)$ pada nilai susut masak. Rerata susut masak untuk waktu stimulasi 0,1 , dan 2 menit secara berurutan adalah 11,27, 14,39, dan 13,78\%. Susut masak selama pemasakan dipengaruhi oleh daya ikat air dari jaringan daging serta kandungan lemak di dalam atau di permukaan daging dan translokasi lemak. Daging berkualitas baik nilai susut masaknya lebih kecil dibanding daging yang berkualitas rendah (Bouton et al., 1971).

Perlakuan tegangan yang berbeda juga berpengaruh nyata $(\mathrm{P}<0,05)$ terhadap susut masak. Rata-rata susut masak dengan perlakuan stimulasi listrik $0,60,75$, dan 90 volt masing-masing 
Tabel 1. Rerata nilai derajat keasaman (pH), daya ikat air, susut masak, dan keempukan daging ayam petelur afkir dengan perlakuan lama stimulasi listrik dengan tegangan yang berbeda ( $p H$ values, water-holding-capacity, cooking loss, and tenderness of culled layer chicken meat subjected to different electrical stimulation treatments)

\begin{tabular}{|c|c|c|c|c|c|c|}
\hline \multirow{2}{*}{$\begin{array}{l}\text { Peubah kualitas fisik } \\
\text { (physical quality) }\end{array}$} & \multirow{2}{*}{$\begin{array}{l}\text { Tegangan } \\
\text { (voltage) }\end{array}$} & \multicolumn{3}{|c|}{$\begin{array}{l}\text { Lama stimulasi (menit) (stimulation } \\
\text { length (minutes)) }\end{array}$} & \multirow{2}{*}{$\begin{array}{l}\text { Rerata } \\
\text { (average) }\end{array}$} & \multirow{2}{*}{$\begin{array}{l}\text { Tegangan x lama } \\
\text { stimulasi (voltage } x \\
\text { stimulation length) }\end{array}$} \\
\hline & & $\mathrm{W}_{0}$ & $\mathrm{~W}_{1}$ & $\mathrm{~W}_{2}$ & & \\
\hline \multirow{5}{*}{$\begin{array}{l}\text { Derajat keasaman } \\
\text { (pH) (pH values })\end{array}$} & $\mathrm{L}_{0}$ & 6,23 & 6,23 & 6,23 & $6,23^{\mathrm{a}}$ & \multirow{4}{*}{$*$} \\
\hline & $\mathrm{L}_{1}$ & 6,23 & 6,14 & 6,05 & $6,14^{\mathrm{a}}$ & \\
\hline & $\mathrm{L}_{2}$ & 6,23 & 6,37 & 5,97 & $6,19^{\mathrm{a}}$ & \\
\hline & $\mathrm{L}_{3}$ & 6,23 & 6,58 & 6,02 & $6,01^{\mathrm{b}}$ & \\
\hline & Rerata (average) & $6,23^{\mathrm{d}}$ & $6,13^{\mathrm{e}}$ & $6,06^{\mathrm{ef}}$ & & \multirow{5}{*}{$*$} \\
\hline \multirow{5}{*}{$\begin{array}{l}\text { Daya ikat air (\%) } \\
\text { (water-holding } \\
\text { capacity (\%)) }\end{array}$} & $\mathrm{L}_{0}$ & 41,02 & 41,02 & 41,02 & $41,02^{d}$ & \\
\hline & $\mathrm{L}_{1}$ & 41,02 & 26,57 & 23,28 & $30,29^{\mathrm{a}}$ & \\
\hline & $\mathrm{L}_{2}$ & 41,02 & 29,95 & 32,25 & $34,41^{\mathrm{c}}$ & \\
\hline & $\mathrm{L}_{3}$ & 41,02 & 22,17 & 31,72 & $31,64^{\mathrm{ab}}$ & \\
\hline & Rerata (average) & $41,02^{\mathrm{d}}$ & $29,93^{\mathrm{e}}$ & $32,07^{\mathrm{f}}$ & & \\
\hline \multirow{5}{*}{$\begin{array}{l}\text { Susut masak }(\%) \\
(\text { cooking loss }(\%))\end{array}$} & $\mathrm{L}_{0}$ & 11,27 & 11,27 & 11,27 & $11,27^{\mathrm{dc}}$ & \multirow{4}{*}{$*$} \\
\hline & $\mathrm{L}_{1}$ & 11,27 & 21,47 & 13,44 & $15,37^{\mathrm{a}}$ & \\
\hline & $\mathrm{L}_{2}$ & 11,27 & 11,61 & 17,45 & $13,44^{\mathrm{b}}$ & \\
\hline & $\mathrm{L}_{3}$ & 11,27 & 13,28 & 12,98 & $12,51^{\mathrm{cb}}$ & \\
\hline & Rerata (average) & $11,27^{\mathrm{d}}$ & $14,39^{\mathrm{e}}$ & $14,78^{\mathrm{e}}$ & & \\
\hline \multirow{5}{*}{$\begin{array}{l}\text { Keempukan }\left(\mathrm{kg} / \mathrm{cm}^{2}\right) \\
\left.\text { (tenderness }\left(\mathrm{kg} / \mathrm{cm}^{2}\right)\right)\end{array}$} & $\mathrm{L}_{0}$ & 5,86 & 5,86 & 5,86 & $5,86^{\mathrm{a}}$ & \multirow{4}{*}{$*$} \\
\hline & $\mathrm{L}_{1}$ & 5,86 & 5,63 & 5,53 & $5,67^{\mathrm{ba}}$ & \\
\hline & $\mathrm{L}_{2}$ & 5,86 & 5,38 & 4,54 & $5,26^{\mathrm{c}}$ & \\
\hline & $\mathrm{L}_{3}$ & 5,86 & 3,79 & 5,02 & $4,89^{\mathrm{d}}$ & \\
\hline & Rerata (average) & $5,86^{\mathrm{d}}$ & $5,16^{\mathrm{ef}}$ & $5,23^{\mathrm{e}}$ & & \\
\hline
\end{tabular}

$\overline{\mathrm{a}, \mathrm{b}, \mathrm{c}, \mathrm{d}}$ Superskrip yang berbeda pada kolom yang sama pada setiap variabel menunjukkan perbedaan yang nyata $(\mathrm{P}<0,05)$ (different superscripts at the same column at the same variable indicate significant differences $(P<0.05)$ ).

d,e,f Superskrip yang berbeda pada baris yang sama pada setiap variabel menunjukkan perbedaan yang nyata $(\mathrm{P}<0,05)$ (different superscripts at the same row at the same variable indicate significant differences $(P<0.05))$.

* Menunjukkan adanya interaksi yang nyata $(\mathrm{P}<0,05)$ (the stars indicate significant interaction $(P<0.05))$.

adalah $11,27,15,37,13,44$, dan 12,51\%. Hal ini berhubungan dengan $\mathrm{pH}$, karena apabila $\mathrm{pH}$ mengalami kenaikan maka susut masak akan menurun, sedangkan hasil penelitian menunjukkan bahwa $\mathrm{pH}$ daging yang distimulasi listrik tidak ada perbedaan yang nyata sehingga susut masak dengan perlakuan stimulasi listrik tidak berbeda nyata. Bouton et al. (1971) menyatakan bahwa suatu kenaikan $\mathrm{pH}$ daging akan meningkatkan jus daging (kenyataan jus dan daya ikat air) dan menurunkan susut masak.

Interaksi yang nyata antara lama stimulasi listrik dengan tegangan yang berbeda menunjukkan bahwa tidak ada perbedaan yang nyata $(\mathrm{P}>0,05)$ terhadap susut masak daging ayam petelur afkir. Hasil penelitian stimulasi listrik menunjukkan nilai susut masak berkisar 6,99 sampai 21,78\%. Nilai ini masih dalam kisaran susuk masak yang normal yaitu 1,5 sampai $54,5 \%$ dengan rata-rata 15 sampai 40\% (Romans dan Ziegler, 1974).

Hasil penelitian menunjukkan bahwa lama stimulasi listrik berpengaruh nyata $(\mathrm{P}<0,05)$ terhadap keempukan daging ayam petelur afkir. Demikian pula, tegangan yang berbeda berpengaruh nyata $(\mathrm{P}<0,05)$ terhadap keempukan daging ayam petelur afkir. Semakin lama waktu stimulasi, keempukan daging semakin meningkat, diduga karena semakin lama waktu stimulasi menyebabkan kontraksi yang lebih besar dan temperatur yang semakin meningkat, sehingga $\mathrm{pH}$ semakin turun. Menurut Soeparno (2005) stimulasi listrik dapat meningkatkan keempukan dan menurunkan $\mathrm{pH}$ daging.

Interaksi antara lama stimulasi listrik dengan tegangan yang berbeda berpengaruh nyata terhadap keempukan daging ayam petelur afkir $(\mathrm{P}<0,05)$, 
yang berarti bahwa keempukan daging ayam petelur afkir merupakan hasil interaksi tegangan dan waktu stimulasi. Hal ini sesuai dengan Soeparno (2005) menyatakan bahwa keempukan daging ditentukan tiga komponen daging yaitu struktur miofibril dan status kontraksi, kandungan jaringan ikat dan daya ikat air, serta jus daging.

\section{Komposisi kimia}

Faktor lama stimulasi dan besar tegangan listrik baik secara tunggal maupun interaksi antara keduanya tidak berpengaruh nyata terhadap ratarata nilai kadar air daging ayam petelur afkir (Tabel 2). Hal ini menunjukkan bahwa nilai kadar air pada setiap kombinasi perlakuan relatif seragam. Hasil yang diperoleh ini sejalan dengan nilai kadar air daging ayam petelur afkir yang juga tidak menunjukkan perbedaan yang nyata.

Umur ayam petelur afkir yang digunakan relatif seumur (sekitar 2,5-3 tahun) dan kondisi tubuhnya relatif kurus, sehingga tidak terdapat deposisi lemak dalam jaringan otot ataupun daging. Menurut Hafid (2008) ternak yang mempunyai kondisi tubuh yang baik dan cenderung gemuk mempunyai kadar lemak yang lebih banyak dan kadar air tubuh yang lebih rendah dan sebaliknya. Menurut Aberle et al. (2001) dan Soeparno (2005) bahwa terdapat korelasi negatif antara kadar air dan kadar lemak tubuh pada ternak.

Pada penelitian ini, kadar air tubuh lebih dominan dibandingkan dengan kadar lemak tubuh ayam petelur afkir ( $49-52 \%$ vs. $2-5 \%)$. Menurut Mountney dan Parkhust (1995) kadar air ayam petelur afkir dapat mencapai $56 \%$, setelah perlakuan, kadar air menurun menjadi 50,69\%. Hal ini disebabkan adanya tegangan akan mengakibatkan semakin tinggi kalori medium yang akan memberi panas pada daging ayam, sehingga banyak air yang teruapkan dan panas yang diserap oleh daging ayam menjadi besar.

Nilai kadar protein daging ayam petelur afkir dengan perlakuan lama stimulasi listrik dan tegangan yang berbeda menunjukkan adanya pengaruh interaksi yang nyata $(\mathrm{P}<0,05)$. Nilai kadar protein tertinggi ditunjukkan oleh kombinasi $\mathrm{L}_{3} \mathrm{~W}_{2}$ sebesar 25,1447 yang lebih tinggi daripada kombinasi lainnya (Tabel 2). Dengan demikian terlihat adanya hubungan linear antara nilai kadar

Tabel 2. Komposisi kimia daging ayam petelur afkir dengan perlakuan lama stimulasi listrik dengan tegangan yang berbeda (chemical composition of culled layer chicken meat subjected to different electrical stimulation treatments)

\begin{tabular}{|c|c|c|c|c|c|c|}
\hline \multirow{2}{*}{$\begin{array}{c}\text { Komposisi kimia } \\
(\%)(\text { chemical } \\
\text { composition (\%)) }\end{array}$} & \multirow{2}{*}{ Tegangan (voltage) } & \multicolumn{3}{|c|}{$\begin{array}{l}\text { Lama stimulasi (menit) (stimulation } \\
\text { length (minutes)) }\end{array}$} & \multirow{2}{*}{$\begin{array}{l}\text { Rerata } \\
\text { (average) }\end{array}$} & \multirow{2}{*}{$\begin{array}{l}\text { Tegangan x lama } \\
\text { stimulasi (voltage } x \\
\text { stimulation length) }\end{array}$} \\
\hline & & $\mathrm{W}_{0}$ & $\mathrm{~W}_{1}$ & $\mathrm{~W}_{2}$ & & \\
\hline \multirow{5}{*}{$\begin{array}{l}\text { Kadar air (water } \\
\text { content) }\end{array}$} & $\mathrm{L}_{0}$ & 51,87 & 51,87 & 51,87 & 51,87 & \\
\hline & $\mathrm{L}_{1}$ & 51,87 & 49,69 & 49,64 & 50,40 & \\
\hline & $\mathrm{L}_{2}$ & 51,87 & 49,50 & 49,47 & 50,28 & \\
\hline & $\mathrm{L}_{3}$ & 51,87 & 49,39 & 49,36 & 50,20 & \\
\hline & Rerata (average) & 51,87 & 50,11 & 50,08 & & \\
\hline \multirow{5}{*}{$\begin{array}{l}\text { Kadar protein } \\
\text { (protein content) }\end{array}$} & $\mathrm{L}_{0}$ & 21,90 & 21,90 & 21,90 & $21,90^{\mathrm{d}}$ & \multirow{5}{*}{$*$} \\
\hline & $\mathrm{L}_{1}$ & 21,90 & 22,32 & 22,28 & $22,17^{\mathrm{c}}$ & \\
\hline & $\mathrm{L}_{2}$ & 21,90 & 22,38 & 24,75 & $23,01^{\mathrm{b}}$ & \\
\hline & $\mathrm{L}_{3}$ & 21,90 & 22,88 & 25,14 & $23,30^{\mathrm{a}}$ & \\
\hline & Rerata (average) & $21,90^{\mathrm{f}}$ & $22,37^{\mathrm{e}}$ & $23,52^{\mathrm{d}}$ & & \\
\hline \multirow{5}{*}{$\begin{array}{l}\text { Kadar lemak (fat } \\
\text { content) }\end{array}$} & $\mathrm{L}_{0}$ & 2,95 & 2,95 & 2,95 & 2,95 & \\
\hline & $\mathrm{L}_{1}$ & 2,95 & 2,06 & 4,77 & 3,26 & \\
\hline & $\mathrm{L}_{2}$ & 2,95 & 4,74 & 2,13 & 3,27 & \\
\hline & $\mathrm{L}_{3}$ & 2,95 & 3,15 & 3,50 & 3,20 & \\
\hline & Rerata (average) & 2,95 & 3,34 & 3,22 & & \\
\hline
\end{tabular}

$\overline{\mathrm{a}, \mathrm{b}, \mathrm{c}, \mathrm{d}}$ Superskrip yang berbeda pada kolom yang sama pada setiap variabel menunjukkan perbedaan yang nyata $(\mathrm{P}<0,05)$ (different superscripts at the same column at the same variable indicate significant differences $(P<0.05))$.

d,e,f Superskrip yang berbeda pada baris yang sama pada setiap variabel menunjukkan perbedaan yang nyata $(\mathrm{P}<0,05)$ (different superscripts at the same row at the same variable indicate significant differences $(P<0.05))$.

* Menunjukkan adanya interaksi yang nyata $(\mathrm{P}<0,05)$ (the stars indicate significant interaction $(P<0.05)$ ). 
protein dengan lama stimulasi dengan besar tegangan. Semakin besar nilai tegangan dan semakin lama stimulasi akan menghasilkan nilai protein yang lebih tinggi pula. Hal sama juga terlihat pada efek mandiri dari kedua faktor, keduanya juga menunjukkan hubungan yang linear.

Pada prinsipnya stimulasi listrik akan mempercepat proses glikolisis postmortem yang terjadi selama konversi otot menjadi daging dan mengubah karakteristik palatabilitas daging termasuk nilai gizi protein (Soeparno, 2005). Namun, penggunaan stimulasi listrik dengan voltase rendah biasanya tidak dapat meningkatkan kualitas dan palatabilitas daging (Bouton et al., 1978).

Perlakuan lama stimulasi listrik dengan tegangan yang berbeda menunjukkan pengaruh yang tidak nyata terhadap kadar lemak daging ayam petelur afkir (Tabel 2). Rata-rata kadar lemak dengan perlakuan stimulasi listrik $0,60,75$, dan 90 volt masing-masing adalah 2,95, 3,26, 3,27, dan $3,20 \%$. Waktu stimulasi juga tidak menunjukkan perbedaan yang nyata pada kadar lemak. Rata-rata kadar lemak untuk waktu stimulasi 0,1 , dan 2 menit secara berturut-turut adalah 2,95, 3,22, dan 3,34\%.

Interaksi antara lama stimulasi dengan tegangan yang berbeda menunjukkan pengaruh yang tidak nyata terhadap kadar lemak daging ayam petelur afkir, hal ini mungkin disebabkan jumlah lemak yang dimiliki sampel ayam petelur afkir sangat sedikit sehingga tidak terlalu berpengaruh terhadap perlakuan stimulasi listrik. Kadar lemak daging sekitar $2,5 \%$ (1,5 sampai $13 \%)$ dan sangat bervariasi (Lawrie dan Ledward, 2006).

\section{Sifat sensori}

Sensori merupakan pengujian terhadap karakteristik bahan pangan dengan menggunakan indera manusia, khususnya indera penglihatan, penciuman, perasa, dan peraba. Uji sensori dalam penelitian ini meliputi warna, aroma, rasa, keempukan, tekstur, dan daya terima disajikan pada Tabel 3.

Perlakuan lama stimulasi listrik dengan tegangan yang berbeda berpengaruh nyata $(\mathrm{P}<0,05)$ terhadap skor warna daging ayam petelur afkir. Hal ini disebabkan karena stimulasi listrik dapat mereduksi pembentukan ikatan serabut kasar pada permukaan lapisan otot dan menyebabkan warna menjadi terang. Daging yang distimulasi dengan tegangan lebih tinggi menghasilkan warna daging yang lebih merah terang dibandingkan dengan tegangan yang lebih rendah, diduga karena panas yang dihasilkan oleh stimulasi listrik dapat mengurangi terjadinya warna yang gelap dan mencegah terbentuknya ikatan kasar. Aberle et al. (2001) menyatakan bahwa stimulasi listrik dapat menyebabkan warna otot menjadi lebih merah terang karena stimulasi listrik mereduksi ke- mungkinan insiden warna daging yang gelap dan pembentukan ikatan serabut kasar pada permukaan lapisan otot.

Perlakuan lama stimulasi listrik dengan tegangan yang berbeda berpengaruh nyata $(\mathrm{P}<0,05)$ terhadap aroma daging ayam petelur afkir, karena pengaruh pemasakan dan teknik proses pengolahan daging dapat menyebabkan kerusakan jaringan pada daging. Aroma daging masak sangat dipengaruhi oleh lama waktu penyimpanan dan kondisi penyimpanan daging setelah dipotong.

Perlakuan stimulasi listrik yang berbeda tidak mempengaruhi aroma daging ayam petelur afkir. Pengaruh aroma mungkin disebabkan karena penentuan aroma oleh panelis yang berbeda-beda, tergantung pada cita rasa. Evaluasi aroma dan rasa sangat tergantung pada panelis cita rasa. Cita rasa daging masak dapat dipengaruhi oleh umur ternak, tipe makanan, jenis kelamin, waktu dan kondisi penyimpanan, serta lama dan temperatur pemasakan.

Perlakuan lama stimulasi listrik dengan tegangan yang berbeda tidak menyebabkan perbedaan yang nyata pada rata-rata skor rasa daging ayam petelur afkir, karena rasa daging ayam afkir relatif sama meskipun telah memperoleh perlakuan lama stimulasi listrik dengan tegangan yang berbeda. Hasil penilaian panelis menunjukkan bahwa rasa daging ayam petelur afkir berkisar antara agak enak sampai enak. Tidak adanya perbedaan rasa ini disebabkan karena komponen rasa sangat didominasi oleh formulasi bahan penyedap dan bumbu yang menghasilkan produk daging proses dengan cita rasa yang berbeda. Dalam penelitian ini tidak dilakukan penambahan penyedap rasa dan pembumbuan (seasoning).

Penambahan bumbu dan bahan-bahan pada penelitian ini dalam jumlah dan komposisi yang sama sehingga diduga menghasilkan rasa daging ayam petelur afkir yang relatif sama pada setiap produk perlakuan meskipun pada metode tegangan dan waktu yang berbeda.

Perlakuan lama stimulasi listrik dengan tegangan yang berbeda berpengaruh nyata $(\mathrm{P}<0,05)$ terhadap keempukan daging ayam petelur afkir. Pada prinsipnya pemasakan dapat meningkatkan atau menurunkan keempukan daging, dan kedua pengaruh pemasakan ini tergantung pada waktu dan temperatur. Temperatur pemasakan lebih mempengaruhi kealotan miofibrilar (Bouton et al., 1978). Protein miofibrilar hampir mengalami koagulasi atau denaturasi sempurna pada temperatur $60^{\circ} \mathrm{C}$, sehingga pemasakan pada temperatur yang lebih tinggi dapat menyebabkan pengeringan dan kealotan protein miofibrilar yang mengalami koagulasi (Hamm dan Deatherage, 1960 cit. Soeparno, 2005). 
Perlakuan lama stimulasi listrik dengan tegangan yang berbeda berpengaruh nyata $(\mathrm{P}<0,05)$ terhadap tekstur daging ayam petelur afkir. Hal ini berhubungan dengan tingkat kekasaran tekstur yang meningkat dengan bertambahnya umur. Otot dengan serabut-serabut otot yang kecil tidak menunjukkan kekasaran tekstur secara nyata dengan meningkatnya umur. Pada umumnya otot ternak jantan mempunyai tekstur yang lebih kasar daripada otot ternak betina. Jenis ternak juga mempengaruhi tekstur otot. Jaringan ikat ternak muda mengandung retikulin dan ikatan silang lebih rendah daripada kolagen jaringan ikat ternak yang lebih tua (Hammond, 1932 cit. Soeparno, 2005).

Tabel 3. Rata-rata skor warna daging, aroma, rasa, keempukan, tekstur, dan daya terima ayam petelur afkir dengan perlakuan lama stimulasi listrik dan tegangan yang berbeda (meat, color score, flavor, taste tenderness, texture, and acceptability of culled layer chicken meat subjected to different electrical stimulation treatments)

\begin{tabular}{|c|c|c|c|c|c|}
\hline \multirow{2}{*}{$\begin{array}{l}\text { Peubah sifat sensori } \\
\text { (sensory panel ratings) }\end{array}$} & \multirow{2}{*}{$\begin{array}{l}\text { Tegangan } \\
\text { (voltage) }\end{array}$} & \multicolumn{3}{|c|}{ Lama stimulasi (menit) (stimulation length (minutes)) } & \multirow{2}{*}{$\begin{array}{l}\text { Rerata } \\
\text { (average) }\end{array}$} \\
\hline & & $\mathrm{W}_{0}$ & $\mathrm{~W}_{1}$ & $\mathrm{~W}_{2}$ & \\
\hline \multirow[t]{5}{*}{ Warna daging (meat color) } & $\mathrm{L}_{0}$ & 2,13 & 2,13 & 2,13 & $2,13^{\mathrm{b}}$ \\
\hline & $\mathrm{L}_{1}$ & 2,13 & 2,53 & 2,33 & $2,33^{\mathrm{a}}$ \\
\hline & $\mathrm{L}_{2}$ & 2,13 & 2,53 & 1,53 & $2,07^{\mathrm{c}}$ \\
\hline & $\mathrm{L}_{3}$ & 2,13 & 1,73 & 1,80 & $1,89^{\mathrm{c}}$ \\
\hline & Rerata (average) & $2,13^{\mathrm{d}}$ & $2,23^{\mathrm{e}}$ & $1,95^{\mathrm{f}}$ & \\
\hline \multirow[t]{5}{*}{ Aroma (flavor) } & $\mathrm{L}_{0}$ & 3,33 & 3,33 & 3,33 & $3,33^{\mathrm{a}}$ \\
\hline & $\mathrm{L}_{1}$ & 3,33 & 2,67 & 2,80 & $2,93^{\mathrm{b}}$ \\
\hline & $\mathrm{L}_{2}$ & 3,33 & 2,33 & 3,00 & $2,89^{\mathrm{b}}$ \\
\hline & $\mathrm{L}_{3}$ & 3,33 & 3,13 & 3,60 & $3,36^{\mathrm{a}}$ \\
\hline & Rerata (average) & $3,33^{\mathrm{d}}$ & $2,87^{\mathrm{e}}$ & $3,18^{\mathrm{d}}$ & \\
\hline \multirow[t]{5}{*}{ Rasa (taste) } & $\mathrm{L}_{0}$ & 3,67 & 3,67 & 3,67 & 3,67 \\
\hline & $\mathrm{L}_{1}$ & 3,67 & 3,93 & 3,73 & 3,80 \\
\hline & $\mathrm{L}_{2}$ & 3,67 & 3,87 & 4,00 & 3,87 \\
\hline & $\mathrm{L}_{3}$ & 3,67 & 3,87 & 4,00 & 3,84 \\
\hline & Rerata (average) & 3,67 & 3,83 & 3,88 & \\
\hline \multirow{5}{*}{$\begin{array}{l}\text { Keempukan daging } \\
\text { (tenderness) }\end{array}$} & $\mathrm{L}_{0}$ & 2,33 & 2,33 & 2,33 & $2,33^{\mathrm{c}}$ \\
\hline & $\mathrm{L}_{1}$ & 2,33 & 2,67 & 2,87 & $2,62^{\mathrm{b}}$ \\
\hline & $\mathrm{L}_{2}$ & 2,33 & 3,07 & 2,47 & $2,62^{\mathrm{b}}$ \\
\hline & $\mathrm{L}_{3}$ & 2,33 & 3,13 & 3,40 & $2,96^{\mathrm{a}}$ \\
\hline & Rerata (average) & $2,33^{d}$ & $2,80^{\mathrm{e}}$ & $2,77^{\mathrm{f}}$ & \\
\hline \multirow[t]{5}{*}{ Tekstur (texture) } & $\mathrm{L}_{0}$ & 3,80 & 3,80 & 3,80 & $3,80^{\mathrm{a}}$ \\
\hline & $\mathrm{L}_{1}$ & 3,80 & 3,13 & 3,40 & $3,44^{\mathrm{bc}}$ \\
\hline & $\mathrm{L}_{2}$ & 3,80 & 3,53 & 2,47 & $3,27^{\mathrm{d}}$ \\
\hline & $\mathrm{L}_{3}$ & 3,80 & 3,40 & 2,73 & $3,31^{\mathrm{c}}$ \\
\hline & Rerata (average) & $3,80^{\mathrm{d}}$ & $3,47^{\mathrm{e}}$ & $3,10^{\mathrm{f}}$ & \\
\hline \multirow[t]{5}{*}{ Daya terima (acceptability) } & $\mathrm{L}_{0}$ & 3,47 & 3,47 & 3,47 & 3,47 \\
\hline & $\mathrm{L}_{1}$ & 3,53 & 3,67 & 3,87 & 3,69 \\
\hline & $\mathrm{L}_{2}$ & 3,73 & 3,80 & 3,80 & 3,78 \\
\hline & $\mathrm{L}_{3}$ & 3,60 & 3,67 & 3,87 & 3,71 \\
\hline & Rerata (average) & 3,58 & 3,65 & 3,75 & \\
\hline
\end{tabular}

$\overline{\mathrm{a}, \mathrm{b}, \mathrm{c}, \mathrm{d}}$ Superskrip yang berbeda pada kolom yang sama pada setiap variabel menunjukkan perbedaan yang nyata $(\mathrm{P}<0,05)$ (different superscripts at the same column at the same variable indicate significant differences $(P<0.05))$.

d,e,f Superskrip yang berbeda pada baris yang sama pada setiap variabel menunjukkan perbedaan yang nyata $(\mathrm{P}<0,05)$ (different superscripts at the same row at the same variable indicate significant differences $(P<0.05))$. 
Perlakuan lama stimulasi listrik dengan tegangan yang berbeda tidak menyebabkan pengaruh yang nyata pada rata-rata skor daya terima daging ayam petelur afkir, yang menunjukkan bahwa daya terima konsumen terhadap daging ayam afkir relatif sama. Daya terima konsumen merupakan gabungan dari beberapa variabel sensori yaitu warna, rasa, tekstur, keempukan, dan aroma. Kesukaan konsumen terhadap produk daging sangat ditentukan oleh rasa atau flavor produk tersebut (Griffin et al., 1985; Aberle et al., 2001). Daging ayam petelur afkir yang sudah distimulasi listrik dengan tegangan yang berbeda memiliki rasa atau flavor yang relatif sama, sehingga daya terima daging ayam petelur afkir juga berbeda tidak nyata. Dalam hal ini, daya terima panelis terhadap produk daging ayam petelur afkir berkisar antara agak suka sampai suka.

\section{Kesimpulan dan Saran}

\section{Kesimpulan}

Berdasarkan hasil penelitian, dapat disimpulkan bahwa stimulasi listrik selama dua menit dengan tegangan 90 volt dapat memperbaiki kualitas fisik dan sensori daging ayam petelur afkir. Interaksi lama stimulasi dan tegangan listrik berpengaruh nyata terhadap kualitas fisik daging seperti $\mathrm{pH}$, daya ikat air, susut masak, keempukan, dan kadar protein daging. Interaksi lama stimulasi dan tegangan listrik dapat memperbaiki kualitas sensori daging seperti keempukan, warna, aroma, dan tekstur daging ayam afkir.

\section{Saran}

Untuk memperbaiki sifat fisik daging ayam petelur afkir, disarankan dapat menggunakan stimulasi listrik dengan voltase tertentu.

\section{Daftar Pustaka}

Aberle, E. D., J. C. Forrest, H. B. Hedrick, M. D. Judge and R. A. Merkel. 2001. Principles of Meat Science. W. H. Freeman and Company. San Fransisco.

Anonimus. 2006. Telur Terimbas Bibit. Available at $\mathrm{http} / \mathrm{www}$.paultryindonesia.com/ modulus php?name $=$ news and life $=$ article and sid=1154. Accession date: 24 Februari, 2009.
Astuti, M. 1980. Rancangan Percobaan dan Analisis Statistik Bagian II. Fakultas Peternakan, Universitas Gadjah Mada, Yogyakarta.

Bouton, P. E., A. L. Ford, P. V. Harris and F. D. Shaw. 1978. Effect of low voltage stimulation of beef carcasses on muscle tenderness and pH. J. Food Sci. 43: 13921396.

Bouton, P. E., P. V. Harris and W. R. Shorthose. 1971. Effect of ultimate $\mathrm{pH}$ upon the waterholding capacity and tenderness of mutton. J. Food Sci. 36: 445-449.

Girard, J. 1992. Technology of Meat and Meat Products. National Institute of Agronomical Research. France.

Griffin, C. L., D. M. Stiffler, C. F. Brasington, G. C. Smith and J. W. Savell. 1985. Effect of electrical stimulation and subprimal storage time on palatability of hot-boned beef. J. Food Qual. 8: 273-281.

Hafid, H. 2008. Strategi Pengembangan Peternakan Sapi Potong di Sulawesi Tenggara dalam Mendukung Pencapaian Swasembada Daging Nasional. Orasi Ilmiah Pengukuhan Guru Besar, Universitas Haluoleo, Kendari.

Judge, M. D., E. D. Aberle, J. C. Forrest, H. B. Hedrick and R. A. Merkel. 1989. Principles of Meat Science. $2^{\text {nd }}$ ed. Kendall/Hunt Publ. Co., Dubuque, Iowa.

Lawrie, R. A. and D. A. Ledward. 2006. Lawrie's Meat Science. $7^{\text {th }}$ ed. Woodhead Publishing Limited, Cambridge.

Mountney, G. J. and C. R. Parkhust. 1995. Poultry Product Technology. $3^{\text {rd }}$ ed. Foof Product Press, on Inprint of the Haworth Press Inc. New York.

Palupi, W. D. 1986. Tinjauan Literatur Pengolahan Daging. Pusat Dokumentasi Ilmiah LIPI. Jakarta.

Romans, J. R. and P. T. Ziegler. 1974. The Meat We Eat. $10^{\text {th }}$ ed. The Interstate Printers and Publishers, Inc. Denville, Illinois.

Santoso, S. 2003. SPSS Versi 10. Cetakan Elex Media Komputindo. Jakarta.

Soeparno. 2005. Ilmu dan Teknologi Daging. Cetakan Keempat. Gadjah Mada University Press, Yogyakarta.

Solomon, M. B. 1986. Response of bovine muscle to Restraints an Electrical Stimulation. J. Anim. Sci. 62: 147-154. 